\title{
$B E$ JANGKRIK dan BE BLUANG SEBAGAI KULINER MUSIMAN di BALI
}

\author{
Ni Nyoman Widani dan A.A Ketut Sri Candrawati \\ Email: wiwin_widani@yahoo.com dan sri.candrawati@pib.ac.id \\ POLITEKNIK INTERNASIONAL BALI
}

\begin{abstract}
Abstrak
Masyarakat petani pedesaan di Bali, mengenal lauk dari jangkrik dan bluang (orong-orong atau anjing tanah). Serangga digunakan sebagai pengganti daging yang harganya mahal. Tujuan penulisan artikel ini adalah untuk memahami gastronomi mengenai be jangkrik dan be bluang dan memperoleh strategi menghindari kepunahan dari sumber hidup bahan utama be jangkrik dan be bluang. Teori yang digunakan adalah teori gastronomi dan teori peternakan. Teknik pengumpulan data yang digunakan adalah wawancara dan studi pustaka.

Hasil penelitian ini menunjukkan jangkrik dan bluang dapat memenuhi kebutuhan protein dan vitamin. Cara untuk mencegah kepunahan kuliner musiman ini adalah dengan menternakkan bahan utama kuliner berupa jangkrik dan bluang. Peternakan juga akan murah dan tidak mudah, dalam waktu singkat juga dapat dipanen. Diperlu eksplorasi sebanyak mungkin kuliner nusantara khususnya Bali sebelum memasuki kepunahannya, dengan harapan Kuliner Tradisional Bali (KTB) dapat bertahan dan terus dilestarikan.

Kata Kunci: Jangkrik, bluang, kuliner, musiman, Bali.
\end{abstract}

\section{Abstract}

Rural farming communities in Bali, recognize side dishes from crickets and bluang (orong-orong or land dogs). The insects are used as a substitute for expensive meat. The purpose of this article is to understand the gastronomy of crickets and be bluang and to obtain strategies to avoid their extinction. The theories used in this research are gastronomic theory and livestock theory and the data collection techniques are interviews and literature studies.

The results of the study showed that crickets and be bluang were very good as seasonal dishes to fulfill the needs of protein and vitamins. The way to prevent this seasonal culinary extinction is to cultivate the main culinary ingredients. The ranch is cheap and easy, and the harvest time is short. It is necessary to do as much culinary exploration as possible, especially the Balinese Traditional Culinary (BTC), with the hope that the culinary can survive and continue to be preserved therefore avoids falling into its extinction

Keywords: Crickets, be bluang, culinary, seasonal, Bali. 


\section{Pendahuluan}

Masyarakat sekarang mengetahui jangkrik hanya dapat dimanfaakan sebagai pakan burung saja. Namun awalnya jangkrik tidak hanya dijadikan sebagai pakan burung tetapi juga dapat dijadikan lauk yang enak dan bermanfaat, terutama oleh masyarakat di daerah pedesaan di Bali dan juga beberapa daerah lainnya di Indonesia. Jenis makanan dari jangkrik ini bahkan sampai sekarang juga masih dinikmati di lingkungan masyarakat Gunung Kidul, Yogyakarta. Jangkrik ini sering dibuat menjadi makanan dan camilan lezat, yang dimasak dalam berbagai cara. Jangkrik dapat hidup di lingkungan kering maupun lingkungan basah, khususnya lingkungan yang berumput. Jangkrik termasuk hewan nocturnal (keluar malam) dan dapat mengeluarkan bunyi nyaring sampai merdu ketika tegumina-nya bergetar saat saling bersentuhan (http://poskotanews.com/2017/11/ 22/pecinta-kuliner-ekstrim-bisa-coba-donat-topping-jangkrik-ini/).

Daging jangkrik yang telah dikeringkan dapat diolah menjadi tepung, yang nantinya dapat dicampurkan dengan bahan-bahan lain berupa ramuan alami sehingga akan menghasilkan produk yang mampu meningkatkan stamina dan kebugaran tubuh.

Selain di pedesaan Bali dan Nusantara umumnya, fenomena mengonsumsi serangga jangkrik juga terjadi di beberapa Negara tetangga. Sebagian penduduk Thailand, telah mengenal adanya kudapan paling populer di negara itu dikenal dengan nama Jing Leed yaitu jangkrik yang dibumbui dengan saus golden mountain mirip dengan kecap. Camilan dari jangkrik ini sering dikatakan sebagai salah satu makanan lezat yang sering dikonsumsi bersama dengan minuman bir (https://tirto.id/mau-kudapanbergizi-makan-serangga-saja-codF).

Masyarakat petani pedesaan di Bali, juga mengenal lauk dari bluang (orong-orong atau anjing tanah) sawah yang enak. Bluang dimasak sebagai pengganti daging hewan yang dirasa harganya terlalu mahal di pasar untuk 
ukuran kantong para petani. Bluang adalah serangga karnivora yang badannya juga mirip seperti jangkrik, namun dapat berlari cepat dan juga bisa terbang hingga sejauh $9 \mathrm{~km}$ dalam musim kawin, dijumpai pada malam hari, pada musim dingin melakukan hibernasi. Serangga ini dapat ditemukan di lubang-lubang di permukaan tanah terutama di sawah, dan pada saat tidak diganggu terutama malam hari akan mengeluarkan suara nyaring seperti jangkrik, tapi nadanya monoton (https://berkahkhair.com/ macam-macam-serangga/).

Berdasarkan latar belakang masalah di atas maka dapat dirumuskan beberapa masalah berkaitan dengan menu kuliner khas Bali (KTB) dari bahan utama serangga jangkrik dan bluang, yaitu: (1) Bagaimanakah gastronomi mengenai be jangkrik dan be bluang? (2) Bagaimanakah strategi menghindari kepunahan dari sumber hidup bahan utama be jangkrik dan be bluang?

\section{Teori dan Metode}

Teori yang digunakan untuk memecahkan masalah dalam artikel ini adalah teori gastronomi dan teori peternakan. Gastronomi mencakup pengetahuan mendetail mengenai makanan dan minuman nasional dari berbagai negara besar di seluruh dunia. Peran gastronomi adalah sebagai landasan untuk memahami bagaimana makanan dan minuman digunakan dalam situasi-situasi tertentu. Teori gastronomi dipergunakan untuk menganalisis masalah pertama pada penelitian ini, khususnya untuk mengkaji mengenai kuliner be jangkrik dan be bluang sebagai kuliner musiman dari segi sejarah hingga penyajian makanan.

Peternakan dalam penelitian ini tergolong peternakan hewan kecil yaitu jangkrik dan bluang, yang dikembangbiakkan dan dibudidayakan untuk mendapatkan manfaat dan hasil. 
Penelitian ini memakai pendekatan holistik berarti cara melihat atau memandang sesuatu sebagai suatu kebulatan yang utuh. Teknik pengumpulan data adalah melalui wawancara dan studi pustaka. Jenis penelitian adalah deskriptif analitis (descriptive analitic) yang bertujuan untuk memeroleh secara jelas tentang suatu situasi atau keadaan tertentu yang ada di lapangan melalui pengumpulan data, dalam hal ini khususnya cara membuat kuliner musiman ini dan kaitannya dengan penyebab terjadinya keterbatasan potensi pasokan bahan alam dan hayati yang ada di daerah Bali saat ini.

\section{Pembahasan}

Kuliner musiman adalah jenis kuliner yang muncul pada saat musim tertentu saja. Jangkrik dan bluang (anjing tanah) sawah yang banyak sekali hidup di persawahan bila telah memasuki musim pasca panen hingga musim kembali membajak di sawah. Saat itulah banyak hidup jangkrik dan bluang di sawah. Jangkrik adalah jenis serangga kecil berkaki enam yang sering dipelihara untuk komersial seperti jenis jangkrik gryllus mitratus dan gryllus testaclus. Selain itu, masih terdapat jangkrik yang diternakan untuk tujuan lain, seperti hobi dan hewan aduan bahkan untuk diolah menjadi makanan musiman.

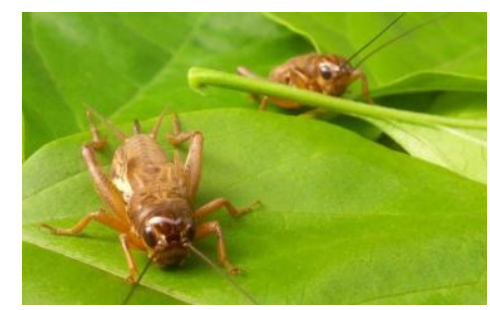

Gambar 1. Jangkrik dengan Ciri-cirinya

Sumber: http://startposter.blogspot.com/2016/11/cara-ternak-jangkrik-denganmudah.html

Bluang adalah sebutan bagi serangga yang berkaki empat dari famili gryllotapidae yang masih serumpun dengan jangkrik. Dalam bahasa Jawa, 
serangga ini biasa disebut orong-orong atau anjing tanah. Dalam bahasa Sunda serangga ini dikenal dengan nama $G a^{\prime}$ ang dan mole cricket dalam bahasa Inggris.

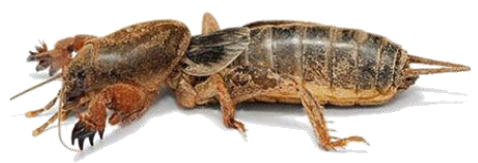

Gambar 2. Bluang dengan Ciri-cirinya

Sumber: http://www.kiat-sehat.com/sajian-serangga-anjing-tanah-yang-dimasakgaya-adobo-di-filipina/

\subsection{Gastronomi Be Jangkrik dan Be Bluang}

Kuliner Tradisional Bali be jangkrik dan be bluang sebagai kuliner musiman di Bali akan dibahas secara lebih mendalam pada subbagian ini. Pemaparan gastronomi kuliner be jangkrik dan be bluang ini akan memaparkan mulai dari lokasi hidup, sejarah, kandungan gizi, dan cara menjadikan masakan dengan bahan utama jangkrik dan bluang dan bahan dan bumbu yang diperlukan hingga cara penyajiannya.

\section{Be Jangkrik}

Salah satu kuliner tradisional Bali yang bersifat musiman adalah be jangkrik (lauk jangkrik) digoreng bumbu manis. Masyarakat petani di pedesaan di Bali sebelum tahun 1980-an sering mengonsumsi daging jangkrik sebagai lauk makan. Namun sejalan dengan kemajuan ekonomi masyarakat Bali, secara perlahan mengonsumsi daging jangkrik mulai hilang.

a) Lingkungan Lokasi $B e$ Jangkrik

Jenis jangkrik yang sering dipakai lauk oleh masyarakat Bali adalah jangkrik kaya (jangkrik yang berukuran lebih besar dari jangkrik pada umumnya), yang dapat diperoleh dari hasil menggali lubangnya, yang dulu sering ditemui banyak bertebaran di pekarangan rumah atau tegalan. Cara menggalinya adalah dengan membongkar tanah di sekitar lubangnya memakai cangkul. Lubang 
jangkrik bisa dikenali dari permukaan lubangnya yang banyak berisi sisa daun atau bunga yang menjadi makanan kesukaan jangkrik. Jangkrik termasuk jenis serangga nocturnal (yang suka keluar malam), dan pada siang hari lebih suka sembunyi pada lubangnya di tanah, atau pada sela-sela bongkahan tanah atau bebatuan, dengan membawa simpanan makanannya masuk ke dalam lubangnya.

Sambil mencari makan di malam hari, jangkrik juga sering mengeluarkan suara nyaring yang berasal dari getaran bulu sayapnya yang saling bersentuhan. Jenis jangkrik yang paling indah suaranya dikenal sebagai jangkrik kalung, berukuran sedang, yang lebih suka hidup di kebun atau sawah yang sedang ngeneng (dibiarkan kering untuk menunggu hari baik kembali memulai mengerjakan sawah basah). Karena indahnya suara jangkrik ini maka oleh masyarakat sering diburu di malam hari (ngintip jangkrik) untuk diternakan sebagai binatang aduan dan juga untuk mengusir tikus. Frekuensi gelombang suara jangkrik sangat tidak disukai oleh tikus sehingga tikus menjauh dari rumah penduduk yang dipenuhi suara jangkrik.

b) Sejarah $B e$ Jangkrik

Seperti diketahui bersama, pada umumnya ekonomi masyarakat petani di pedesaan adalah sangat rendah, sehingga dalam menopang segala kebutuhan hidup keluarganya selalu berusaha berhemat. Karena tantangan itu, petani menjadi sangat kreatif dalam memanfaatkan sumber daya alam sebagai bahan pengganti bahan pangan yang lebih mahal. Salah satu kreatifitas yang dilakukan adalah mencari sumber bahan pangan yang tersedia di lingkungan alam sekitarnya, yang pada musim-musim tertentu cukup tersedia melimpah, salah satunya adalah memanfaatkan serangga jangkrik sebagai bahan lauk. Cara paling sederhana dan paling murah dalam memasak daging jangkrik (ditambus yaitu dibungkus daun pisang 
berlapis dengan diberi bumbu sambal, minyak dan garam lalu ditanam dalam abu bara api dapur sampai matang). Cara yang lebih kompleks adalah dengan menjadikan jangkrik goreng bumbu manis, yang dikerjakan oleh ibu rumah tangga bila persediaan jangkrik cukup banyak.

Di zaman postmodern ini menu kuliner dari daging serangga dan jangkrik khususnya kembali mulai menjadi tren baru. Cara mengolah daging jangkrik agar sampai menjadi makanan menarik pun mengalami perkembangan penuh kreatifitas tinggi, sehingga bisa masuk ke gerai toko-toko modern.

c) Kandungan Daging Jangkrik

Daging jangkrik mengandung vitamin B, zinc dan magnesium lima kali lebih banyak dari daging sapi. Bahkan jangkrik memiliki rendah kalori, namun kaya akan omega tiga, serat dan kalsium (http://poskota news.com/2017/11/22/pecinta-kuliner-ekstrim-bisacoba-donat-topping-jangkrik-ini/). Komposisi daging jangkrik telah diteliti secara ilmiah dan berdasarkan hasil Penelitian dan Pengetahuan (Litbang) ASTRIK (Asosiasi Peternak Jangkrik Indonesia) diperoleh informasi bahwa jangkrik memiliki banyak manfaat karena memiliki kandungan, sebagai berikut: (a) Gizi dan Hormon. Jangkrik mengandung 105.49 ppm hormon progesteron, $31.78 \mathrm{ppm}$ testoteron, dan $259.535 \mathrm{ppm}$ estrogen, serta dapat dijadikan sumber energi penting bagi tubuh, dan energi yang dihasilkan sebesar 4.87 kalori/gram. (b) Protein. Kandungan protein pada daging jangkrik yang telah diolah menjadi tepung juga sangat tinggi yaitu $57.32 \%$. Protein yang terdapat dalam daging jangkrik jauh lebih banyak dari pada protein yang terdapat pada daging ayam, sapi, dan udang. (c) Jangkrik juga mengandung DHA9, asam amino yang diperlukan untuk proses pembentukan sel, glutation (GSH) yang 
berguna untuk antioksidan pada tubuh, DHA, ARA, omega tiga, dan omega enam yang baik untuk pertumbuhan dan perkembangan kecerdasan otak anak-anak.

Protein dan asam-asam amino yang terdapat pada jangkrik juga mampu mencegah terjadinya penyempitan pembuluh darah dan stroke. Selain itu, bagi wanita, daging jangkrik juga mampu menunda proses menopouse. Daging jangkrik juga dapat mencegah penyakit penuaan dini karena adanya protein collagen yang mampu mempertahankan elastisitas persendian tulang, sel kulit, kornea mata, dan mencegah penyakit katarak, sehingga orang bisa lebih awet muda.

d) Bahan dan Bumbu Be Jangkrik Goreng

Dalam membuat kuliner be jangkrik goring dibutuhkan beberapa bahan, yaitu sebagai berikut: jangkrik setengah kg, minyak goreng satu liter, gula pasir 250 gr, penyedap rasa setengah sendok makan, garam empat sendok makan, dan air bersih kurang lebih dua liter. Bumbu pembuatan jangkrik goreng manis ini, yaitu: bawang merah 15 siung, bawang putih 10 siung, dapat ditambah sedikit (seruas ujung jari) kencur, cabe rawit lima 5 biji (bisa ditambah bila suka pedas). Semua bahan bumbu ini dihaluskan menjadi satu, lalu sisihkan.

e) Cara Membuat $\mathrm{Be}$ Jangkrik Goreng

Siapkan jangkrik yang masih segar. Kemudian seduh jangkrik dengan air mendidih agar mati dan kotorannya mudah lepas. Lalu cuci dengan air bersih beberapa kali untuk menghilangkan kotoran yang masih ada melekat pada jangkrik, sisihkan.

f) Cara Memasak Jangkrik Goreng

Siapkan panci di tungku dapur lalu tuang air bersih sebanyak kurang lebih dua liter dan panaskan sampai mendidih, lalu masukan bumbu halus (bawang putih, bawang merah dan kencur ditambah gula 
pasir, garam, yang telah dihaluskan) ke dalamnya, dan tambahkan sedikit penyedap rasa. Kemudian masukkan jangkrik yang sudah bersih, masak selama \pm 30 menit sampai matang agar rasa bumbu meresap ke dalam daging jangkrik. Setelah matang, angkat dan tiriskan jangkrik selama lima menit, agar saat digoreng minyaknya tidak meledak-ledak akibat pecahnya melekul air, yang bisa memerciki tangan dan badan hingga melepuh.

Kemudian siapkan wajan di tungku, isi minyak goreng secukupnya dan panaskan. Setelah minyak cukup panas baru masukan jangkrik yang telah direbus dengan bumbu halus tadi, goreng sampai berwarna kecoklatan sebagai tanda matang. Lalu angkat dan tiriskan, agar bebas dari minyak. Simpan di dalam wadah saji atau toples. Sebagai catatan, saat membuat jangkrik goreng jangan sampai menggunakan gula bali atau gula merah (gula kelapa atau gula aren) ke dalam campuran bumbunya karena dapat menyebabkan jangkrik cepat gosong saat proses penggorengan.

Sebenarnya, daging jangkrik juga bisa diolah secara kreatif dengan cara lain agar sama-sama menjadi menarik dan enak untuk dikonsumsi manusia. Caranya jangkrik dibalut dengan tepung bumbu waktu akan menggorengnya. Tepung bumbu yang paling sederhana bisa dibuat dari beras yang dihaluskan lalu dicampur dengan bumbu halus tersebut di atas. Bagi yang suka rasa lebih berani, bumbu halusnya dapat dibuat dari bahan base genep yang dihaluskan, tergantung selera dan dana yang tersedia. Goreng sampai garing.

Cara sederhana lain untuk pengolahannya, yaitu jangkrik yang akan diolah terlebih dahulu dinyanyah (digongseng yaitu digoreng tanpa menggunakan minyak) supaya lebih gurih. Jangkrik kering itupun kemudian dapat diolah lagi, misalnya dijadikan sebagai rempeyek, sate, biskuit, maupun campuran dalam nasi goreng atau 
olahan lainnya. Terdapat beberapa jenis pengolahan jangkrik menjadi beberapa jenis menu menarik tersebut, seperti: cheese stick cheekrik, rempeyek jangkrik, nasi goreng jangkrik, jing leed (jangkrik), es dawet jangkrik, dan gongseng jangkrik.

\section{g) Cara Penyajian}

Rempeyek jangkrik memiliki tekstur yang crispy, rasanya gurih, dengan keunikan khas daging jangkrik akan langsung terasa. Kedua menu kuliner ini dapat dijadikan camilan, dan juga pas untuk lauk saat makan. Cukup disajikan bersama nasi putih dan sayur dan sambal. Karena memiliki sifat camilan maka dapat disajikan setiap waktu, tetapi bila untuk lauk, enak disajikan bersamaan di setiap waktu makan nasi.

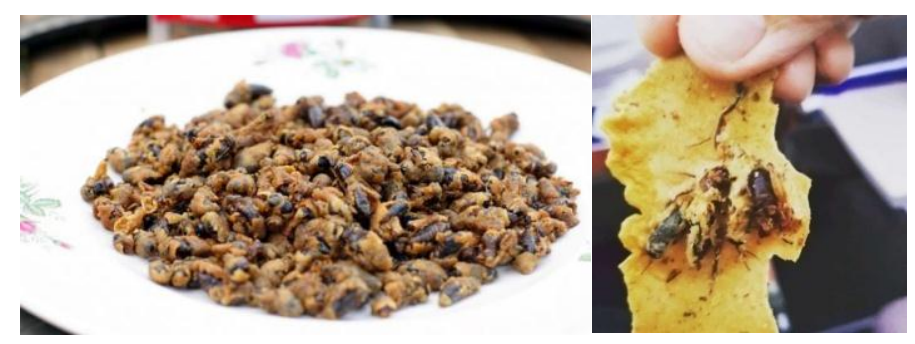

Gambar 3. Keripik dan Jangkrik Goreng Sumber:

https://www.google.co.id/search?q=kuliner+menu+jangkrik+di+yogya\&hl

\section{Be Bluang}

Anjing tanah, oleh orang Bali disebut bluang, orang Jawa menyebut orong-orong, di tanah Sunda disebut gaang, sementara dalam bahasa Toba disebut singke. Bluang pada masa lampau juga sering diolah menjadi lauk makan musiman oleh masyarakat petani pedesaan di Bali.

\section{a) Lingkungan Lokasi Be Bluang}

Serangga yang bernama anjing tanah ini ternyata dapat ditemui di hampir seluruh lingkungan wilayah di bumi kecuali di darah kutub. 
Binatang ini membuat lubang di permukaan tanah sebagai tempat tinggal. Anjing tanah adalah mahkluk nocturnal atau keluar aktif di malam hari. Hewan ini agak jarang terlihat di siang hari karena lebih suka bersembunyi dalam lubang dan baru aktif pada malam hari mencari makan. Sama dengan jangkrik, habitat yang disukai adalah ladang yang kering, pekarangan rumah, dan lapangan rumput. Lingkungan hidup bluang juga ada di sawah yang ngeneng (masa pasca panen padi yang dibiarkan kering) sehingga permukaan tanah pecah-pecah dan tumbuh rumput gulma lebat yang dapat menjadi sarang persembunyian hidup bluang.

Hewan ini pada musim dingin melakukan hibernasi dan dapat menghasilkan suara melalui mekanisme mirip jangkrik (dengan organ stridulasi). Suaranya bersifat monoton (ngee......eet tanpa jeda) dan amat mengganggu pendengaran. Bila lubang persembunyiannya didekati, orong-orong akan berhenti bersuara (http://surgaserangga. blogspot.com/2012/08/orong-orong.html).

\section{b) Sejarah Be Bluang}

Bluang akan banyak muncul dan keluar disaat mulainya musim membajak di sawah, karena lubang persembunyiannya dirusak dan digenangi air. Hal ini menginspirasi dan memudahkan para petani menangkapnya untuk dijadikan lauk musiman. Saat mulai turun bekerja pengolah tanah ini, sawah akan mulai dialiri air agar tanahnya menjadi lunak dan mudah dibajak, sehingga genangan air ini akan pengganggu kehidupan bluang di sarangnya sehingga bluang keluar menyelamatkan diri. Pada saat bersamaan pekerjaan pembajakan secara tidak langsung juga merusak lubang-lubang tempat persembunyian bluang, sehingga dipaksa keluar mengambang dan berenang di air sawah. Kesibukan membajak ini juga sering langsung dimanfaatkan oleh para petani sebagai sambilan untuk menangkap 
bluang-bluang itu, dimasukan ke dalam kantong penyimpanan khusus agar tidak kabur dan agar mudah dibawa pulang. Kesempatan ini juga berarti sekaligus sebagai jeda istirahat sesaat sebelum kembali melanjutkan pekerjaan membajaknya. Setelah istirahat pulang, barulah bluang-bluang itu dimasak sebagai lauk makan sore atau malam.

c) Kandungan Be Bluang

Serangga bluang ini memiliki kandungan protein yang tinggi sehingga sangat bagus jika dikomsumsi sebagai bahan substitusi penganti lauk dari hewan seperti sapi, ayam, babi, dan sebagainya. Karena kandungan proteinnya tinggi maka oleh para peternak burung juga sering dijadikan pakan burung ternakan, diberikan pada jenis burung penyanyi atau berkicau seperti murai batu, kacer, anis merah, dan sebagainya. Daging bluang mengandung moisture 71,20\%, protein $15,40 \%$, lemak $6,30 \%$, serat $1,70 \%$ dan energi 125,10 kalori. Serangga ini juga memiliki kandungan asam amino esensial (omega 3) serta mineral dalam jumlah lebih banyak daripada hewan ternak seperti ayam, sapi, dan kambing (https://omkicau.com/2015/ 03/19/kandungan-gizi-beberapa-jenis-serangga-untuk-burungkicauan/).

d) Bahan dan Bumbu Be Bluang

Be bluang tidak hanya telah dikonsumsi masyarakat Bali di pedesaan sejak lampau, tetapi juga banyak dikonsumsi di negara Asia lainnya. Di kawasan Asia Timur, anjing tanah terkadang digoreng untuk disantap manusia. Di Tiongkok, sekresi orong-orong dimanfaatkan sebagai campuran obat-obatan herbal (https://ala mendah.org/2010/12/11/anjing-tanah-atau-orong-orong/). Di Bali sering dibuat lauk sederhana dengan bumbu dadah atau ditumis. Bahan-bahan Be Bluang Medadah (lauk bluang tumis) adalah bluang 
(orong-orong) sawah setengah $\mathrm{kg}$, minyak goreng seperempat liter, gula pasir $250 \mathrm{gr}$, penyedap rasa setengah sendok makan, garam empat sendok makan, air dua liter, kelapa setengah butir, yang diparut (bisa diparut halus atau diparut gobed, melebar tipis). Bahan bumbu halus be bluang medadah yang sangat sederhana hampir sama dengan bumbu jangkrik goreng, yaitu bawang merah 15 siung, bawang putih 10 siung, dapat ditambah sedikit (seruas ujung jari) kencur, dan cabe rawit lima biji (bisa ditambah bila suka pedas). Semua bahan bumbu ini dihaluskan menjadi satu, lalu sisihkan. Kalau ingin rasa yang lebih beragam dan tajam dapat dipakai bumbu base genep (bumbu Bali lengkap dengan jenis bebungkilan atau jamu-jamuan).

e) Cara Membuat Be Bluang Medadah

Siapkan bluang (orong-orong) sawah setengah kg yang masih segar. Kemudian seduh dengan air mendidih agar mati dan kotorannya mudah lepas. Lalu tarik kepalanya sampai putus dan bagian isi perutnya ikut tetarik keluar untuk dibuang. Pemutusan kepala bluang juga bertujuan untuk membersihkan bluang dari sepasang tungkainya yang keras dan kasar agar nantinya tidak ikut termakan. Lalu cuci dengan air bersih beberapa kali untuk menghilangkan kotoran yang masih ada melekat pada bluang, sisihkan.

f) Cara Memasak Be Bluang Medadah

Bluang yang sudah bersih dan akan diolah dengan cara medadah atau ditumis terlebih dahulu dinyanyah (digongseng yaitu digoreng tanpa menggunakan minyak) supaya garing dan nanti bumbu dadahannya bisa meresap kedalam daging bluang dan akan terasa lebih gurih. Bluang yang telah kering itupun kemudian baru diolah kembali menjadi be bluang medadah. 
Caranya mendadah, masukan minyak goreng sedikit ke wajan lalu panaskan. Setelah minyak panas kemudian bumbu halus (campuran bawang putih, bawang merah, kencur, cabe, garam) dimasukan ke dalam minyak digoreng sebentar sampai muncul bau harum dan sedap pertanda bumbu sudah matang. Lalu tuang air bersih sebanyak dua liter ke dalam wajan berisi bumbu matang tersebut dan panaskan sampai mendidih. Kemudian masukkan parutan kelapa dan bluang yang sudah digongseng, dan diaduk agar bercampur merata, sambil dicicipi dan ditambah garam dikit demi sedikit agar tidak keasinan. Semua itu didadah sampai airnya habis atau kering, agar rasa bumbu meresap ke dalam daging bluang, dan juga dapat ditambah sedikit penyedap rasa (pitsin). Setelah air dadahan nyaat (habis, kering) berarti be bluang medadah sudah matang, lalu diangkat dan ditaruh di atas piring saji.

Gongsengan bluang juga dapat diolah kembali ke dalam berbagai menu berbeda seperti pada membuat be jangkrik goreng di atas. Sebenarnya, daging bluang juga bisa diolah secara kreatif dengan cara lain seperti misalnya dijadikan sebagai rempeyek, sate, biskuit, maupun campuran dalam nasi goreng atau masakan olahan lainnya.

Di Filipina khususnya di Provinsi Pampanga yang terkenal sebagai pusat kuliner Filipina, juga sangat terkenal punya sajian jenis serangga enak yang renyah dan gurih. Salah satunya adalah sajian eksotis populer berbahan bluang yang disebut camaro (mole cricket) yang dapat ditemui melimpah di Pampanga. Tumisan orong-orong atau anjing tanah ini dikenal dengan adobong camaro. Camaro (bluang) biasanya diberi bahan dari soy sauce, cuka, garam dan lada. Untuk menambah cita rasa, camaro ditumis bersama cincangan bawang putih, bawang bombai, dan irisan tomat. Ada yang memanasi 
camaro terlebih dahulu baru memasaknya sampai bumbu kering meresap.

g) Cara Penyajian

Be bluang medadah atau anjing tanah yang selesai ditumis dapat disajikan di atas takir (lipatan daun pisang) atau di atas piring kecil. Disajikan dengan nasi putih pada piring lain, ditambah sambal bongkot (pohon atau bunga kecicang muda) yang diolah mirip sambel matah dan sayur urap. Sifat asam irisan bongkot dapat menawar bau khas dari bluang, dan menjadi lebih enak.

Waktu penyajian yang pas pada waktu sore atau malam hari. Rasa santan parutan kelapa dan bumbunya sangat terasa masuk ke dalam daging bluang .

\subsection{Strategi Menghindari Kepunahan Sumber Hidup dari Bahan Utama Be Jangkrik Dan Be Bluang}

Strategi terbaik yang dapat dilakukan adalah dengan ternak jangkrik dan bluang. Hal ini memungkinkan karena ilmu pengetahuan tentang kehidupan bluang sudah sangat dipahami dan sudah banyak dilakukan oleh masyarakat di sekitar wilayah Kecamatan Gunung Kidul, Yogyakarta. Serangga jangkrik dan bluang mudah diternak, pakannya sedikit, tidak butuh lahan pengangonan (gembalaan), berkembang biak secara cepat dan hampir tidak menghasilkan emisi gas rumah kaca (https://www.dw.com/id/sehatnya-menyantap-serangga/a-17650121).

Di Indonesia, banyak jangkrik dipelihara untuk ternak jangkrik komersial adalah gryllus mitratus dan gryllus testaclus. Bibit atau indukan ternak jangkrik sebaiknya didapat dari tangkapan alam. (http://startposter.blogspot.com/2016/11/cara-ternak-jangkrik-denganmudah.html). Metamorfosis pada hewan jangkrik sekitar 83 hari melalui tiga tahapan yakni telur, nimfa, dan jangkrik dewasa. Pada tahap telur akan 
berlangsung selama tiga hari kemudian menetas. Pada tahap nimfa akan berlangsung selama 40 hari untuk menjadi imago dan siap untuk bereproduksi contoh hewan ovipar (https://dosenbiologi.com/manusia/ contoh-hewan-metamorfosis-tidak-sempurna).

Beberapa spesies orong-orong, seperti gryllotalpa orientalis, $G$. hirsuta, G. africana, G. hexadactyla, dan G. brachyptera yang dapat diternakan. Satu indukan jantan mampu membuahi 10 indukan betina. Telur orong-orong akan menetas setelah 15 hari. Orong-orong dapat dipanen setelah umur 35 hari. Dari 30 pasang indukan orong-orong dapat dipanen hasil orong-orong segar sebanyak 1000-1200 ekor orong-orong dewasa siap jual (https://www.kompasiana. com/jamalrajajangkrik/599ac 88d3364943058085ef2/cara-beternak-oro-ng-orong).

\section{Penutup}

Masyarakat petani pedesaan memiliki kreatifitas memasak bahanbahan yang juga diambil kebanyakan berasal dari sumber hayati dan alami dari lingkungan pertanian. Di antara preferensi jenis masakan yang mungkin cukup asing kedengarannya bagi kalangan generasi yang lahir di atas tahun 1980-an adalah jenis masakan be jangkrik goreng manis dan be bluang medadah. Namun sejalan dengan perkembangan ilmu pengetahaun dunia tentang insekta maka juga berpengaruh terhadap perubahan orientasi masyarakat dunia, yang kembali ke alam mulai kembali mempertimbangkan serangga untuk dapat dijadikan sumber protein dan vitamin bagi dunia yang telah sesak. Di samping kandungan protein dan vitaminnya yang tinggi, serangga bila sudah diolah dengan baik rasanya juga sangat lezat. Sudah seharusnya masyarakat mulai dari pedesaan sampai perkotaan memulai membiasakan diri dan lebih sering menyantap masakan dari serangga. 
Masalah kelangkaan sumber hayati dari serangga jangkrik dan bluang mudah dapat diatasi dengan cara peternakan. Ternak jangkrik dan bluang dapat menjadi bahan substitusi alternatif bagi penemuhan kebutuhan pangan dunia di masa depan akibat terbatasnya atau mahalnya sumber daya hewani. Di samping mudah diternak, pakan ternak serangga jangkrik dan bluang juga jauh lebih sedikit dari sapi, kambing, atau babi, tidak butuh lahan pengangonan (gembalaan), berkembang biak secara cepat dan hampir tidak menghasilkan emisi gas rumah kaca.

Mengapresiasi kuliner lokal dengan memasak di dapur sendiri, menjadi langkah paling nyata dalam melestarikan budaya KTB. Dengan apresiasi yang berbasis dari rumah, dari dapur sendiri, masakan lokal akan menjadi tuan rumah di negeri sendiri. Untuk itu agar kuliner nusantara khususnya KTB tidak punah, memang harus ada standarisasi proses pengolahan dalam bentuk resep. Standarisasi resep itu penting kalau tidak kehilangan cita rasa khas tradisi setempat di masa mendatang. Dan kalau masakan tradisional daerah sudah mulai kehilangan standarnya, lama lama akan bisa kehilangan rasa unggulnya.

Namun untuk menyelamatkan jenis kuliner tradisi ini sangat perlu sekali diadakan penerapan praktek dari identifikasi dan dokumentasi resep dalam bentuk lomba memasak kuliner musiman setempat. Sangat penting bagi pemerintah daerah untuk melaksanakan banyak event KTB masa lampau yang sudah terlupakan. Pelaksanaan event-event KTB ini bertujuan untuk mengeksplorasi sebanyak mungkin kekuatan kuliner nusantara khususnya Bali sebelum memasuki kepunahannya, dengan harapan KTB dapat bertahan dan terus dilestarikan. 


\section{Daftar Pustaka}

Ariani, Risa Panti. 2017. Mengenal Kuliner Bali. Jakarta: Rajawali Pers, PT. Raja Grafindo Persada.

Bungin, Burhan. 2001. Metodologi Penelitian Sosial. Surabaya: Universitas Airlangga.

Cohen, E., dan Avieli, N. 2004. "Food in Tourism: Attraction and Ompediment". Annals of Tourisme Research. Vol 31 (4), hlm. 597-617.

Remen, I Ketut. 1987. Olah-olahan Paebatan Bali. Tanpa penerbit.

Sudiara, Putu Bagus. 1999. Tata Boga. Jakarta: Depdikbud.

Surayin, Ida Ayu. 2007. Masakan Bali. Surabaya: Paramita.

Susilo, Edi. 2010. Dinamika Struktur Sosial Dalam Ekosistem Pesisir. Malang: Universitas Brawijaya Press.

Wrasiati, Luh Putu, Wijaya, I Made Anom Sutrisna, Suter, I Ketut, Wiranatha, A.A. Putu Suryawan. 2017. Kuliner Tradisional Bali (Balinese Traditional Culinary). Denpasar: Udayana University Press.

\section{Informan:}

1. Nama : I Wayan Sabeh

Alamat : Lingkungan Tengah, Desa Adat Lukluk, Mengwi, Badung, Bali

Umur : 78 tahun

2. Nama : Made Kesiar

Alamat : Lingkungan Badung, Desa Adat Lukluk, Mengwi, Badung, Bali

Umur : : 76 tahun

3. Nama : Ni Nyoman Pineh

Alamat : Lingkungan Badung, Desa Adat Lukluk, Mengwi, Badung, Bali

Umur : $: 70$ tahun

4. Nama : Wayan Kariawan

Alamat : Lingkungan Badung, Desa Adat Lukluk, Mengwi, Badung, Bali

Umur : 54 tahun

\section{Studi Internet:}

Anonim. 2010. Anjing Tanah atau Orong-orong. (serial online). [cited 2017 Des. 5]. Available from URL: https://alamendah.org/2010/12/11/anjingtanah-atau-orong-orong/.

Anonim. 2015. 10 Contoh Hewan Metamorfosis Tidak Sempurna Terlengkap. (serial online). [cited 2017 Des. 5]. Available from URL: https://dosen biologi.com/manusia/contoh-hewan-metamor fosis-tidak-sempurna.

Anonim. 2016. Cara Ternak Jangkrik dengan Mudah. (serial online). [cited 2017 Des. 5]. Available from URL: http://startposter.blogspot.com/2016/11/ cara-ternak-jangkrik-dengan-mudah.html.

Anonim. 2017. Cara Beternak Orong-orong. (serial online). [cited 2017 Des. 5]. Available from URL: https://www.kompasiana.com/jamalrajajangkrik/ 599ac88d3364943058085ef2/cara-beternak-orong-orong. 
Anonim. 2017. Sajian Seranggaa Anjing Tanah yang Dimasak Gaya Adobo di Filipina. (serial online). [cited 2017 Des. 5]. Available from URL: http://www.kiat-sehat.com/sajian-serangga-anjing-tanah-yang-dimasakgaya-adobo-di-filipina/.

Anonim. 2017. Serangga Sebagai Makanan. (serial online). [cited 2017 Des. 5]. Available from URL: https://www.pinterpandai.com/ kuliner-makananserangga-goreng-thailand/.

Debora, Yantina. 2017. Mau Kudapan Bergizi? Makan Serangga Saja. (serial online). [cited 2017 Des. 5]. Available from URL: https://tirto.id/maukudapan-bergizi-makan-serangga-saja-codF.

Gino, Raden. 2017. Macam Macam Metamorfosis Pada Hewan. (serial online). [cited 2017 Des. 5]. Available from URL: https://mathe mathikaku.blogspot.com/2017/03/macam-macam-metamorfosis-padahewan.html.

Khair. 2016. 50 Gambar dan Spesies Serangga yang Ada di Sekitarmu. (serial online). [cited 2017 Des. 5]. Available from URL: https://berkahkhair. com/macam-macam-serangga/.

Munandi, Aries. 2015. Kandungan Gizi Beberapa Jenis Serangga untuk Burung Kicauan. (serial online). [cited 2017 Des. 5]. Available from URL: https://omkicau.com/2015/03/19/kandungan-gizi-beberapa-jenisserangga-untuk-burung-kicauan/.

Osterath, Brigitte. 2014. Sehatnya Menyantap Serangga. (serial online). [cited 2017 Des. 5]. Available from URL: https://www.dw.com/id/sehatnyamenyantap-serangga/a-17650121.

Pratama, Randy Satria. 2012. Orong - Orong. (serial online). [cited 2017 Des. 5]. Available from URL: http://surgaserangga.blogspot.com/2012/08/ orong-orong.html.

Safira, Maya. 2016. Di Filipina Ada Sajian Serangga Anjing Tanah yang Dimasak Gaya Adobo. (serial online). [cited 2017 Des. 5]. Available from URL: https://food.detik.com/info-kuliner/d-3152466/di-filipina-ada-sajianserangga-anjing-tanah-yang-dimasak-gaya-adobo.

Tri. 2017. Pecinta Kuliner Ekstrim Bisa Coba Donat Topping Jangkrik Ini. (serial online). [cited 2017 Des. 5]. Available from URL: http://pos kotanews.com/2017/11/22/pecinta-kuliner-ekstrim-bisa-coba-donattopping-jangkrik-ini/.

Wibisono, Nuran. 2017. Serangga Akan Jadi Penyelamat Krisis Pangan. (serial online). [cited 2017 Des. 5]. Available from URL: https://tirto.id/ serangga-akan-jadi-penyelamat-krisis-pangan-cuBH

Wikipedia. 2017. Gastronomi. (serial online). [cited 2017 Oct. 2]. Available from URL: https://id.wikipedia.org/wiki/Gastronomi.

Wikipedia. 2017. Peternakan. (serial online). [cited 2017 Oct. 2]. Available from URL: https://id.wikipedia.org/wiki/Peternakan. 


\section{Profil Penulis}

Ni Nyoman Widani, S.S.,M.Hum lahir di Br. Tegal Gundul, 16 Desember 1968. Menyelesaikan Pendidikan SDN 2 Pekandelan Klungkung Bali 1981, SMPN 2 Klungkung Bali thn 1984, SMEAN Klungkung Bali thn 1987 Pendidikan Diploma 1 Akomodasi Perhotelan di PPLP Dhyana Pura Denpasar thn 1989 Menyelesaikan pendidikan S1 pada Fakultas Sastra Inggris Universitas Warmadewa Denpasar tahun 1998 Pendidikan selanjutnya adalah menyelesaikan pendidikan S2 Magister Ilmu Linguistik di Universitas Warmadewa pada tahun 2017. Memiliki pengalaman dalam mengajarkan bahasa Inggris di berbagai tempat pelatihan dan lembaga pendidikan serta memiliki lembaga pelatihan sendiri yaitu Aladdin English Training. Saat ini tercatat sebagai dosen D3 Seni Kuliner pada Politeknik Internasional Bali.

\section{A.A Ketut Sri Candrawati, S.S.,M.A lahir di Br. Anyar, 18 Agustus} 1974 adalah dosen D3 Seni Kuliner di Politeknik Internasional Bali. Menyelesaikan Pendidikan Sarjana (S1) di Universitas Warmadewa Fakultas Sastra Bahasa Inggris tahun 1997 dan program Magister (S2) di Universitas Tujuh Belas Agustus 1945 (UNTAG) surabaya Jurusan Administrasi pada tahun 2014, mimiliki kemampuan Bahasa Inggris yang baik dan memiliki cukup kemampuan pada bahasa Jerman, Jepang, dan Perancis. Tahun 2007-2013 mengajar Bahasa Inggris di tempat kursus Bahasa Inggris dan SMK Margarana, Tabanan. Mengajar bidang Administrasi di STISIP Margarana, Tabanan. 